folk/ed. Derg, 2020; 26(1): 127-139

DOI: 10.22559/folklor.1091

\title{
Zildjian'lar ve Türk Zilleri
}

\author{
Zildjian's and Turkish Cymbals
}

\section{Canan Aykent}

\begin{abstract}
$\ddot{O} \mathbf{z}$
Bronz çağında keşfedilen zil, en eski enstrümanlar arasındadır. Asya coğrafyasında metal işlemeciliğinin gelişmesi bu keşfin temel kaynağı olarak görülmektedir. Çin, Türk ve Mısır kavimleri yüzyıllar boyunca zil üretiminde ve müzikal olarak kullanılmasında başat rol oynamışlardır. Gerek savaş ve istilalar gerekse ticaret aracılığıyla diğer kıta ve toplumlara taşınan bu enstrüman, tarihsel süreçte malzeme ve şekil olarak toplumların normlarına göre değişim/dönüşüm geçirmiştir. Zillerin önem kazanması 17. Yüzyılda Mehteranla gerçekleşmiş, sarayın kazancı başı Kerope Zildjian, zil yapımında uzmanlaşarak yaklaşık 400 yıllık bir mirasın öncüsü olmuştur. Babadan oğula geçen üretim bilgileri ve melekeleri uzun süre sır olarak saklanmış, “Türk zilleri” efsane haline gelmiştir. 20. Yüzyıl başında ABD’ne yerleşen Zildjian ailesinin İstanbul'da kalan üyesi Mikhail Zilçan 1977 yılına kadar zil yapımına devam etmiş, bu tarihten sonra yanında yetişen çıraklar bu mirası devam ettirmişlerdir. Metalin enstrümana dönüştürülmesi, alaşımın hazırlanmasından damgalanmasına kadar her aşamada belirli bir uzmanlık gerektirmektedir. Zildjian firması da dahil olmak üzere günümüzde mekanik üretim yaygındır. El yapımı üretim ise usta-çırak ilişkisiyle öğrenilmekte, tüm aşamaların elde gerçekleşmesi neticesinde her bir zil kendine has tınıya sahip olmaktadır. Bu nedenle Türkiye'de üretilen ziller el yapımı olmaları itibariyle dünya çapında değerlerini korumaktadırlar. Geçmişten gelen ve günümüzde devam eden bu geleneğin sürdürülmesi, kültürün yaşatılması ve müzik sanatına katkısı açısından gurur vericidir.
\end{abstract}

Geliş tarihi (Received): 03 Şubat 2019 - Kabul tarihi (Accepted): 25 Kasım 2019

* Dr., T.C. Kültür ve Turizm Bakanlığı Vurmalı çalgılar sanatçısı. cananaykent@yahoo.com.tr. ORCID ID: 0000$0002-1212-425 X$. 
Bu makalede Türk zillerinin yaratılmasını sağlayan Zildjian ailesi ve bu zillerin teknik özellikleriyle tanıtılması hedeflenmiştir. Literatür taraması sürecinde Osmanlı İmparatorluğu dönemine ilişkin verilerin henüz yeterince ortaya çıkmamış olduğu tespit edilmiştir. Bununla beraber elde edilen bilgilerle Zildjian ailesi ve bu isimle özdeşleştirilen Türk zilleri hakkında gerek kronolojik gerekse betimsel bir çerçeve oluşturulduğu düşünülmektedir.

Anahtar sözcükler: müzik, zil, alaşım, el yapımı, Zildjian

\begin{abstract}
Cymbal was discovered in the Bronze Age and it is among the oldest instruments. The development of metalwork in Asian geography is seen as the main source of this discovery. Chinese, Turkish and Egyptian tribes played a major role in the production and musical use of cymbals for centuries. The instrument, which was transported to other continents and countries either by means of war and invasions or trade, has undergone various changes and transformations in terms of material and shape based on the social customs and habits in history. The importance of cymbals has increased with Janissary Band in the $17^{\text {th }}$ century. The copper smith of the palace, Kerope Zildjian was specialized in the making of cymbals and became a pioneer of 400 years of heritage. The knowledge of production and crafting has passed from father to son and has been kept as a secret for a long time, resulting in "Turkish cymbals" becoming legends. Mikhail Zilçan, a member of the Zildjian family, who moved to America in the beginning of the $20^{\text {th }}$ century, had stayed in İstanbul, and continued to produce cymbals until 1977. After this date, his apprentices helped to sustain this heritage. The conversion of the metal into the instrument requires specific expertise at every stage, from preparation of the alloy to sealing. Nowadays, including the Zildjian Company, it is more common to use mechanical production. Handmade production is learnt through master-apprentice relationship and since all the production stages are hand-crafted, each cymbal in the end, has its own, unique timbre. In Turkey, cymbals are still crafted by hand and therefore they preserve their worldwide value. The continuation of this longlasting tradition until today is very honoring for the survival of culture and for contributing to the art of music.
\end{abstract}

The article aims to introduce the Zildjian family, who are the founders of Turkish cymbals and the technical features of these cymbals. The literature review proved that the archival material of the Ottoman Empire period are still mostly unrevealed. However, the light of the acquired information, the article provides a chronological and descriptive framework on the Zildjian family and the Turkish cymbals, associated with the family name.

Keywords: music, cymbal, alloy, handmade, Zildjian 


\section{Giriş}

Enstrümanlar içinde idiofon ${ }^{1}$ sınıflandırmasında yer alan ziller, vurmalı çalgılar ailesindendir. Pirinç ve bronz alaşımlardan çanak şeklinde üretilirler. Membranofonların² pes frekanslarına kontrast oluştururlar. Elle birbirlerine çarptırılarak ya da bir düzenek üzerinde vurularak çalınırlar. Zil, bronz çağından beri vurmalı çalgıların en egzotik örneklerinden biri olmuş hem keskin hem buğulu, gizemli tınılarıyla ruhani törenlerin işitsel boyutuna derinlik katmıştır. Antik zamanlardan beri Asya ve Ortadoğu coğrafyasında temel ritim enstrümanlarından biri olarak kullanılmış, 14. Yüzyıldan 19. Yüzyıla kadar Osmanlı İmparatorluğu’nun Mehteran takımında yer almıştır. 18. Yüzyıldan itibaren Avrupa senfonik müziğinde ve bandolarda görülmeye başlanan ziller, 20. Yüzyılla birlikte popüler müziğin gelişmesiyle özellikle caz müziğinde ayrı bir değer kazanmıştır. Zaman içinde değişen müzik türleriyle beraber farklı çeşitleri ortaya çıkmıştır. Zil üretimi temelde metallerin karıştırılarak işlenmesi olarak görülse de son aşamada müzik enstrümanına dönüşmesi, işlemler silsilesini özel kılmaktadır. Yüzyıllardır alaşımın hazırlanması sır olarak saklanmıştır. Türkiye'de üretilen ziller gerek geçmişte gerekse günümüzde dünya çapında üne sahiptir. Bu anlamda organoloji çalışmaları içinde "Türk zili" kavramından söz etmek mümkündür.

$\mathrm{Bu}$ çalışmada zillerin bilinen en eski enstrümanlardan biri olması, Asya, Ortadoğu ve Anadolu kökenleri üzerinden gelişmesi, gelişmeyle beraber efsaneleşmesinde en büyük rolü oynayan Zildjian ailesinin önemi, babadan oğula geçen geleneği yüzyıllardır sürdürmeleri, bu mirasın aile dışı sınırlara taşması ve günümüzde Türk firmalar tarafindan halen yaşatılması incelenmeye çalışılmıştır.

\section{Tarihsel süreçten kesitler}

Çin, Hint, Mısır, Ortadoğu ve Anadolu, çalgılara dair en eski buluntuların keşfedildiği coğrafyalardır. Membranofonlar, dünyanın her yerinde görülürken, ziller adı geçen coğrafyalarda doğmuş ve dünyaya bu merkezlerden yayılmışlardır. Metalin işlenmesi Bronz çağı ile ilişkili olduğundan zillerle ilgili ilk bilgiler de bu döneme uzanmaktadır. M.Ö. 3000'e tarihlendirilen bulgular, Asya coğrafyasına aittir. M.Ö. 1200'lü yıllarda, Anadolu'da tanrıça Kibele'ye ibadet edilen zamanlarda, dinsel törenlerde zillerin, seslerinin parlaklığıyla tanrıların yüceltilmesinde törenin görkemini arttırmak amaçlı kullanıldığı bilinmektedir (Blades, 2005: 165). Ayrıca Kilikia bölgesinde mezarlara ölü hediyesi olarak konulan örneklere İkiztepe, Horoztepe ve Alacahöyük'de rastlanmaktadır (Tunçer, 2005: 41). Ortadoğu coğrafyasında ise M.Ö. 1050 y1lında Eski Ahit'in, Samuel, Günlükler, Ezra, Nehemia, Mezmurlar ve Davud'un meselelerinin ilahi olarak okunduğu Psalm bölümlerinde zillerden söz edilmektedir. Davud, Kudüs'e geldiğinde İsrail halkı onu arplar, kornetler, zil ve diğer enstrümanlarla karşılamışlardır. Törenlerde kullanılan bu enstrümanlar kutsanmış ve yüksek dereceli müzisyenlerce çalınmaktadırlar (Blades, 2005: 168). Mısırlılarda zilin, M.Ö. 850 yıllarında var olduğunu Amon tapınağının müzisyeni Ankhape'nin mumyasında bulunan örnek kanıtlamaktadır. Bronzdan dökülmüş olan parça, yaklaşık $16.5 \mathrm{~cm}$ çapında, $3.8 \mathrm{~cm}$ kalınlığındadır. Yine Mısır'da ilerleyen dönemlerde ve Kıptiler zamanında "parmak zilleri” ve "zilli maşa"nın ortaya çıktığı görülmektedir. M.Ö. 700-600 yıllarına ait Babil fresklerinde ve tabletlerde davul çalan erkeklere zil çalan kadınların eşlik ettiği tespit edilmiştir. $\mathrm{O}$ dönem zillerin şekilleri kısmen günümüzdekilere benzerlik göstermektedir. Zil çanakları, nadiren düz, çoğu göbeklidir. Küre ve daha farklı biçimlere sahiptirler. Büyüklük- 
leri 20-25cm arasındadır ve tını farklılıkları gözetilmiştir. Zaman zaman dikey, zaman zaman yatay kullanılmışlardır. Yatay şekilde çalınan zillere örnek, Babil heykelciklerinde arpa eşlik eden çift zillerdir. Bunlar çanak şeklindedir ve yaklaşık $12.7 \mathrm{~cm}$ büyüklüğündedir ve birbirine vurmak suretiyle çalınmaktadırlar (Blades, 2005: 166-167). Çin'de metal disklerin kullanımı Orta Çăğ' da batı komşularıyla olan savaş ve ticaret yoluyla gerçekleşmiştir. M.S. 1101'de Ch'en Yang'ın yazdığı "Çin Müzik Enstrümanları” kitabında bu enstrümanların Tibet'ten geldikleri belirtilmiştir. Öte yandan yalnızca Tibet’ten değil, Asya coğrafyasında yaşayan Türk ve Hintlilerin de etkisi olduğu düşünülmektedir. M.S. 384'de Kutcha Krallığının fethinden sonra Çin İmparatorluk sarayında zillerin de çalındığı Doğu Türkistan'lı bir orkestranın varlığı kayıtlardadır. Orta Avrupa da aynı dönemde metal işçiliğinde uzman olan Avar ve Hunlar vasıtasıyla zilleri tanımışlardır (Sachs, 1940: 207). Hindistan'a da yine Hunlar'ın istilasıyla geldiği M.S. 5. Yüzyılda Garwha'daki tapınağın rölyeflerinden çıkarılmıştır (Sachs, 1940: 222). Ziller, müzikal ve törensel amaçlar dışında düşmana korku salmak amacıyla da işlev görmüşlerdir. Çinlilerin ve Mısırlıların zilleri rastgele ve kuvvetle birbirine çarptırarak yarattıkları kaotik sesler düşmana dehşet, korku salmıştır (Redmond, 1997: 99). Zillerin kullanım konuları medeniyetler geliştikçe çeşitlenmeye başlamıştır. Şenliklerde, cenazelerde, büyücülerin ay tutulmaları gibi kozmik olayların etkilerini hafifletmekte, arı avcılarının bronz tınılarla arıları yakalamaları gibi çeşitli faaliyetlerde etkili oldukları düşünülmekte (Pinksterboer, 1992: 15), Roma kültüründe küçük bronz çanakların, enstrüman, baharat, sirke ve içki kadehleri olarak kullanıldığı bilinmektedir. Pompei yıkıldığında ebatları birbirinden farklı ziller kalıntılarda bulunmuştur (Beck, 1995: 169).

Askeri bandolar tarihinde zillerin dünya çapında ünlenişi Osmanlı İmparatorluğu'nun Mehter takımı dönemindedir. Mehteranda ziller çift olarak çalınmakta ve değneğe geçirilmiş hilal biçimli metala takılı çıngıraklardan oluşan çevgân da bulunmaktadır. Avrupa askeri bandolarına girişleri ise Osmanlıların Avrupa topraklarına yaptıkları istilalar sırasında Mehter takımının çaldıkları müzikler vasıtası ve etkisiyle 18. Yüzyıldan sonra gerçekleşmiştir (Tanrıkorur, 2003: 24). Mehteran için zil döken ve tarih içerisinde bu enstrümanların gelişmesine ve ünlenmesine en çok katkıda bulunan 396 yıldan beri 10 kuşaktır üretimde olan Zildjian ailesidir.

\section{Zil ile özdeșleştirilen efsane: "Zildjian"}

17. yüzyıl başlarında, Tuğlacı'ya göre Karadeniz kıyılarından, Cohan'a göre Doğu Anadolu'daki savaş ve huzursuzluklardan kaçan Ermenilerden biri olarak (Cohan, 1999: 7) İstanbul'a gelip yerleşen I. Kerope'nin bakırcılıkla uğraşmakta olduğu bilinmektedir. Sarayda kazancı başı olarak çalışan Kerope, 1618'de Padişah I. Mustafa'nın izniyle Topkapı surlarının arkasında zil üretmek üzere bir atölye kurmuş daha sonra bunu Samatya semtine taşımıştır (Tuğlacı, 1986: 47). Öldüğünde yerine oğlu I.Avedis (1596-?) geçerek saray için çalışmaya devam etmiş, metal dökümlerin yanı sıra yeniçerilere kılıç ve kalkan yapmıştır³. I. Avedis, 1623 yılında, Samatya'daki atölyede kalay-bakır karışımından yeni bir bronz alaşım keşfederek buna göre zil üretmeye başlar. Yaptığı alaşım oldukça değerlidir. Tını çok güzeldir ve kolay kırılabilir değildir. Mehteran için ziller, Ermeni ve Rum kiliseleri için çanlar üretmeye başlar. "Zildjian” ismi Türkçe zil ismine, Ermenice oğlu, ailesi anlamına gelen -ian ekinin katılmasıyla oluşmuştur. Zillerinin kalitesiyle çok büyük saygınlık kazanan Avedis’ten sonra yerine oğlu Ahkam geçer. Böylelikle babadan oğula geçen gelenek zinciri başlamış olur. Ahkam 1651 yılı civarında babasından işi devralır (Cohan, 1999: 8). 


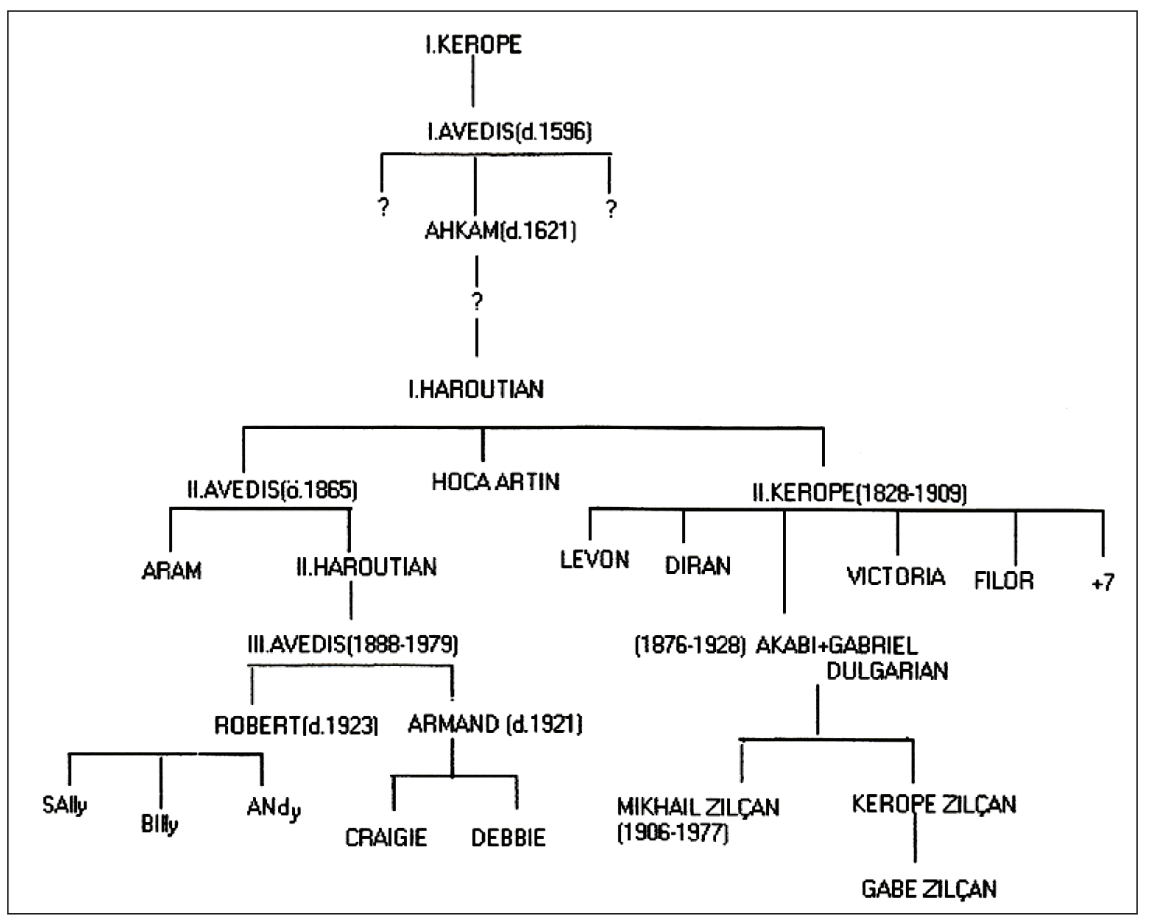

Şema: Zildjian ailesi soy ăgact

Kaynak: (Pinksterboer, 1992: 140), (Tuğlact, 1986: 48-49), (Cohan, 1999: 8)4

Yaklaşık 200 sene boyunca Zildjian'lar hakkında pek bir bilgiye rastlanmamaktadır. 1800'lü yıllara gelindiğinde Ahkam'ın torununun oğulları, II. Avedis, II. Kerope ve Hoca Artin'den bahsetmek mümkün olur. 17. Yüzyıldan itibaren Avrupa klasik müzik repertuarında ${ }^{5}$ ve askeri bandolarında yer almaya başlayan zillerin popülerlik kazanmasıyla II. Avedis, 1851 ve 1862 yıllarında Londra Uluslararası Sergilerine Osmanlı İmparatorluğu temsilcilerinden biri olarak katılır. Ticari amaçlı, endüstriyel üretim yöntemlerinin ve ürünlerinin tanıtımına yönelik bu fuarlarda Osmanlı Devleti, ülke topraklarının verimliliğini, tarım, sanayi ve sanat alanlarındaki iyileştirmelerini Avrupa’ya göstermeyi amaçlamaktadır (Adıgüzel, 2019: 158). II. Avedis, fuarlarda zillerinin kalitesiyle büyük başarı elde eder. 1865 yılında Avedis'in vefatıyla kardeşlerden II. Kerope, işin başına geçerek aynı yıl isimleri adına şirket kurar. 1867 yılında Dünya Paris Sergisi’ne katılır ve Zikr-i Cemil Madalyası'ına layık görülür (Tuğlacı, 1986: 50).

1868 yılında ise Hazine-i Evrak'ın Meclis-i Vâlâ İradeleri bölümünde yer alan bir dilekçede Hoca Artin'in ve akrabalarının art arda yangın felaketleri yaşadıkları ve sermayelerini kaybederek bundan dolayı birikmiş borçlarını hazineye ödeyemedikleri, bu yüzden üretim için gerekli olan hammaddeyi de sağlayamadıkları belirtilmektedir. Sultan Abdülaziz sunulan bu arz tezkeresi üzerine "Zilciyan" ailesine her türlü yardımın yapılmasını ve borçlarının belli şartlarla ödenmesini buyurmuştur (Tuğlacı, 1986: 48-49). II. Kerope'nin ilerleyen y1llarda, 1873'te Viyana'da, 1883'te Boston'da, 1888'de Bologna'da, 1893'de Chicago'da sergilere katıldığg ve madalyalar kazandığı görülür (Tuğlac1, 1986: 52). Zilleri, rezonans, 
incelik ve sağlamlık açısından Avrupa'daki üretimlere göre daha üstündür. 1800'lü yılların sonlarında atölyede yılda yaklaşık 1300-1500 arası zil üretilmektedir. II. Kerope, 1909 yılına kadar firmanın başında yer alır ve ertesi yıl vefat eder. Vefatından sonra 12 çocuğundan, iki oğlu Diran (ö.1921) ve Levon işi devam ettirirler. II. Avedis'in oğlu Aram da onlara katılır. Aram, 1905 yılının temmuz ayında Ermenilerce tasarlanan Sultan II. Abdülhamid'e suikast teşebbüsüne karışır, bunun üzerine Bükreş’e sürüldüğü veya kaçmak zorunda kaldığı yönünde iddialar yer alır. Bükreş’te "Zildjiaram” ismiyle zil yapmaya devam eder (Pinksterboer, 1992: 143) ve “A.Zildjian \& Cie" adıyla şirket kurar. Aram, İstanbul'daki atölyeyle bağlantı içindedir ve oradaki firma "K.Zildjian \& Cie" adını taşımaktadır (Cohan, 1999: 9). Bu dönemde imalathanenin idaresini II. Kerope’nin büyük kızı Victoria üstlenmiştir. Aram’ın 1926 yılına kadar Bükreş’te kaldığı sonrasında İstanbul'a döndüğü düşünülmektedir.

II. Kerope'nin bir diğer kızı Akabi, Gabriel Dulgarian'la evlenir. Bu evlilikten Mikhail ve Kerope kardeşler dünyaya gelir. Mikhail de zil yapımını öğrenmek istemektedir ve bu maksatla Bükreş'e Aram'ın yanına gider. Aram'ın ona gizli formülü öğretmediği anlaşılmaktadır. Mikhail'in soyadı Dulgarian'dır. Soyadı kanununun çıkmasıyla “Zilçan” ismini alır. İstanbul'a döndüğünde bir süre konservatuvarın şan bölümüne devam eder. 1908 yılında Aram'ın kardeşinin oğlu III. Avedis ABD’ne göç etme kararı alır, Boston'a yerleşir ve şeker imalatıyla uğraşır. Çocukluğunda İstanbul'daki atölyede çalışmıştır. 1927 yılında amcası Aram'dan tekrar zil üretimine başlamalarını isteyen bir mektup alır. III. Avedis isteksizdir ve onun için zil üretmek uzak bir hayalden ibarettir fakat ABD’nde gerek dönemin popüler müziği olan cazda gerek senfonik orkestralarda kullanılan ziller Zildjian'dır (Cohan, 1999: 15-16). O dönemde İstanbul'daki atölyede Mikhail Zilçan üretime devam etmektedir ve 1926 yılından beri ABD'nde dağıtım haklarını davul seti firması olan Fred Gretsch'e vermiştir (Pinksterboer, 1992: 150-151, Cohan, 1999: 9). III. Avedis, böylelikle potansiyel olduğunu keşfeder ve teklifi kabul eder. Aram'ın da ona katılmasıyla 1929 yılında Massachusettes Norfolk Downs'da atölye kurarlar. Müzik endüstrisi Türkiye'den gelmeyen zilleri başta kabul etmek istemez. Bunun üzerine III. Avedis Harlem'deki kulüpleri dolaşarak davulcularla temasa geçer ve onların isteklerine göre ziller üretmeye başlar. Gerek Birinci Dünya Savaşı gerekse 1929 ekonomik krizi, müzik dünyasında da değişimlere yol açmıştır. Büyük ve küçük orkestralarda çalınan müzikler değişmiş, toplumsal/bireysel beğeniler, zaman, mekân ve sosyo-ekonomik yapıya göre şekillenmiştir. Bu bağlamda vurmalı enstrümanlarda da yapısal değişiklikler görülür. Davul setinde farklı ebat ve tınılarda ziller fonksiyonlarına göre şekillenir. III. Avedis' in birebir davulcularla temasa geçmesi yeni zillerin yaratılmasında baş rolü oynar (Cohan, 1999: 19, 24).

İstanbul'daki firmayı 1923 yılında Sağmalcılar semtine taşıyan Mikhail Zilçan, ilerleyen yıllarda Yako S. Toledo ve Ehrenstein isimli yabancı ortaklarla üretimi devam ettirmeye çalışır. 1940 yılında şirket, Toledo'nun damadı Salomon Covo tarafından iflasın eşiğinden kurtarılır. Covo yönetimi devralır. 1950 yılında Avedis Zildjian firması tüm isim haklarına sahip olur. Aileye evlilik yoluyla dahil olup zil üretenlerin "Zildjian” adını taşımaya hakları olmadığını bildirirler. Mikhail Zilçan'ı hedefleyen bu bildiriye rağmen İstanbul'daki atölyede "K.Zildjian" damgası uzun yıllar kullanılır. Zilçan vefatına kadar çalışmaya devam eder (Pinksterboer, 1992: 142-144, Cohan, 1999: 75). 
Öte yandan ABD'nde 1979 yılında vefat eden III.Avedis'in yerine büyük oğlu Armand geçer. Zildjian firması oldukça büyümüş, üretim mekanik, otomatik ve fabrikasyon sisteme dönmüştür. Firmayı 1999 yılından beri Arman'ın kızları Craigie ve Debbie yönetmektedirler (Cohan, 1999: 124). Armand'ın kardeşi Robert Zildjian ise 1981 yılında Kanada'da "Sabian" ismi altında kendi firmasını kurar. Sabian, Robert'ın Sally, Billy ve Andy adındaki çocuklarının isimlerinin ilk hecelerinin birleşmesinden oluşan isimdir ${ }^{6}$.

\section{3. "Türk Zili" devam ediyor: "İstanbul" ve ötesi}

Mikhail Zilçan'ın atölyesinde yetişen iki çırak, zil üretiminde Türkiye'nin sesini dünyaya duyurmaya devam ederler. Agop Tomurcuk(yan) 1941 senesinde doğmuş, abileri Oksant ve Gabris gibi Samayta'daki atölyede 9 yaşından itibaren çalışmaya başlamıştır. 1940 doğumlu Mehmet Tamdeğer de aynı atölyeye 10 yaşında girer. Tamdeğer, atölyenin yakınlarında oturduğunu ve çalışanların Ermeni olduğunu, zil yapımına merakından dolayı ustalardan iş istediğini bu şekilde atölyeye girdiğini dile getirmektedir. O dönemde Mikhail Zilçan, "İngiliz” lakaplı Kirkor Küçükyan ustayla beraber çalışmaktadır. Çıraklar, üretimin her aşamasını öğrenirler fakat Mikhail usta alaşımı kendisi yalnızken hazırlar. Onların bu sırrı öğrenmeleri kendi ifadeleriyle şu şekilde olur: "Mikhail ustamızın bakır ve kalayları nasıl karıştırdiğını, erittiğini çatıdaki delikten nefesimizi tutarak izlerdik. Artık formül bizdeydi. Tatbikat için hem çalışıp hem de ă̆zımızı fermuarlayıp bekledik"’. Mikhail Zilçan'ın 1977 yılındaki vefatına kadar üretim sürer, Tomurcuk ve Tamdeğer orada çalışmaya devam ederler. Atölyenin kapanması sonucu Agop Tomurcuk akrabalarının yardımıyla Bakırköy-Kartaltepe'de küçük bir imalathanede zor şartlar altında üretime başlar. Zilleri İstanbul'daki mağazalarda tek tük satılır. Mehmet Tamdeğer de bu işi devam ettirmek istemektedir. 1980 yılında iki usta beraber Bağcılar semtinde yeni bir atölye oluştururlar ve "Zilciler Kolektif Şti”ni kurarlar. İki yıl içinde büyük ilerleme kaydederler ve ithalata başlarlar. Aynı dönemde "Zilciler" ismini "İstanbul" olarak değiştirirler (Onat, 1997: 13). Atölyede 9-10 kişi eski usullerle el yapımı üretim gerçekleştirmektedir. Üretilen ziller eski K'lara çok benzemektedir. Zil dünyasındaki eski K'lar kavramı, Zildjian'ların İstanbul' dayken ürettikleri zillerden kaynaklanmaktadır. Zile vurulan K damgası, Kerope'nin baş harfidir. Bu zillerin pürüzlü tınıları uzun yıllar caz davulcuları tarafından oldukça beğenilmiştir. Artık üretilmediklerinden koleksiyoncular için ayrı bir değer taşımaktadırlar. Unutulmamalıdır ki 1929 yılından beri ABD’nde üretime devam eden Zildjian firması uzun zamandır makine yöntemiyle fabrikasyon sisteme geçmiştir. Gerek bu nedenle gerek İstanbul zillerinin eski K'larla olan benzerliğinden ötürü yeni üretilen ziller dünya çapında, özellikle caz çalanlar arasında çok beğenilir. 1982-1996 yılları arasında İstanbul zilleri kaliteleriyle giderek ünlenirler ve "Türk zili” namını yeniden yaşatmayı başarırlar. ABD, Almanya, Fransa, Benelux ülkeleri, Yeni Zelanda, Japonya, Güney Afrika, Mısır, Suudi Arabistan gibi dünyanın pek çok ülkesine ithalatları genişler (Onat, 1997: 13). 1996 yılında Agop Tomurcuk'un vefatıyla çocukları Sarkis ve Arman bir sene sonra önce "İstanbul Zilciler" ardından “İstanbul Agop" adıyla ayrı bir firma kurarlar. Mehmet Tamdeğer de "İstanbul Mehmet" ismiyle bir firma kurarak ayrılır. Yine İstanbul firmasında yetişen bazı ustalar başka atölyeler de açarlar. Bu firmaların önde gelenleri “Turkish” ve “Bosphorus”tur. Türkiye'deki tüm atölyelerde ustadan çırağa öğretilen, halen en değerli teknik olan elle üretim devam etmektedir. 


\section{Zil yapımı metotları ve aşamaları}

\section{1. Zil yapımı metotları}

Zil yapımı, elle üretim, makinayla üretim ve ikisinin karışımından oluşan metotlarla gerçekleşmektedir. Elle üretimde, alaşımın hazırlanmasından itibaren son aşamaya kadar el emeğinin varlığı söz konusudur. Makine, bilgisayar teknolojisinde bu durum tam tersine işlemektedir. Karışık tekniklerde ikisi bir arada kullanılmaktadır. El yapımında hiçbir zil birbirinin aynısı olmamakta dolayısıyla her bir zil kendine özgü tınıya sahip olmaktadır ki bu da onu biricik ve tekil kılmaktadır. Artin Çerkezoğlu ve Mehmet Tamdeğer ustalara göre eskilerden bugüne çok şey değiştiyse de el yapımı zillerin her zaman çok zengin bir karakteri olduğunu belirtmektedirler (Bir Dünya İnsan-Zilci, 2017). Zildjian'lardan bu yana Türkiye'de üretilen tüm ziller el yapımıdır. Makine-bilgisayar teknolojisini Avrupa ve ABD'ndeki firmalar kullanmaktadırlar. Bu metotta her zil tam olarak birbirinin aynısı olarak seri üretilmektedir. Deneyimlerime göre iki metot arasında fark, genellikle sesteki parlaklık, doğuşkanların çokluğu ve özgünlükten kaynaklanmaktadır.

\subsection{Zil yapımı aşamaları}

Zil yapımında üç aşama söz konusudur. Alaşım, çekiçleme ve torna.

\subsubsection{Alaşım}

1980'li yılların sonlarına doğru üreticiler iki tür bronz alaşım yapmaya başlamışlardır. Birincisi B20 ismiyle bilinen \%80 bakır, \%20 kalay, ikincisi B8 denilen \%92'si bakır, \%8'i kalay olan alaşımlardır. Her ikisinde de ufak tefek diğer metaller karıştırılabilmektedir. Ayrıca pirinç ve nikel-gümüş alaşımlar da vardır. Sır, alaşımın oranlarında değil hazırlanma şeklindedir. Hangi sıcaklıkta, hangi düzende, hangi metaller eklenir gibi unsurlarda saklıdır. Arman Zildjian, "Bizim sırrımız malzemenin karışımında değildir. Belli reçetesi yoktur. Büyükannenin yaptığı pasta gibi zaman içinde deneme yanılma yoluyla geliştirilen bir tekniktir" demektedir (Pinksterboer, 1992: 115). İşlemin hazırlanma aşamasında firındaki sıcaklık çok önemlidir. El yapımı zil üretenler ısıtmada eski usul odun ateşi tercih etmektedirler. Alaşım, firınlarda sıvı hale getirilir ve kalıplara/tavalara dökülür. Kalıbın içinde çapraz dönerek her geçişte farklı yöne yayılır. Bunun sonucunda eşit kalınlığa ve eşit moleküler dağılıma ulaşılır, düz diskler elde edilir. B8 alaşımında metalde grenler tek yöne doğru akarlar. B20'deyse metaller farklı yönlere hareket ederler dolaysıyla B20'lerin kaliteleri daha yüksek olur ve profesyonel zillerde kullanılırlar. Tavadan çıkarılan diskler silindirde çekildikten sonra tavlanırlar. Bu işlem 10-12 defa tekrar edilmektedir çünkü silindirden ilk çekildiğinde disk sertleşmeye başlar. İstenilen kıvam elde edildikten sonra göbek oluşturulur ve kenarları kesilir. Ardından çekiçleme aşaması gelir ${ }^{10}$.

\subsection{2. Çekiçleme}

Üç tip çekiçleme vardır. Bilgisayar-otomatik kontrollü, mekanik ve elle. Hepsinin kendine özgü pozitif ve negatif yönleri söz konusudur. Kimi zaman birkaç teknik bir arada kullanılır. Elle çekiçlemedeki düzensiz darbeler seste heterojenlik sağlar. Makinelerle durum tam tersinedir. Önce zilin alt yüzeyi çekiçlenir. Ardından üst yüzey çekiçlenirken kavis verilmeye başlanır ve tekrar alt yüzey çekiçlenerek son şeklini alır (Pinksterboer, 1992: 75-76). Üreti- 
min en önemli aşamalarından biri biçim verilmesidir. Bir zili çekiçlerken şekil, her vuruşta oluşur ve metal belirli noktalarda daha bastırılmış olur. Bu yüzden de ses sadece zilin şekline değil, çekiçlemenin biçimine, vuruşların gücüne, sayısına, dağılımına da bağlıdır. Öte yandan zillerin her iki ya da tek tarafının çekiçlenmesi de sesini etkiler. Her dövmeci kendi çekiçleme stiline sahiptir. Bu stil vuruş tarzına göre değişiklik gösterir (Keskin, 2016).

\subsubsection{Torna}

Ziller hem tornadan geçmiş hem tornalanmamış şekilde kullanılabilmektedirler. Tornalanmamış olanlarda yüzeyde çekiç darbelerini görmek mümkündür ve doğuşkanlar sınırlıdır çünkü zildeki ses değişiklikleri tornalamayla da ilgilidir. Tornalama, zilin farklı bölgelerindeki düzensizliği giderir. Yüzey homojenlik kazanır, incelir ve parlar. Bu işlemle zilin derinliği, biçimi ve genişliği son aşamasına ulaşır (Keskin, 2016).

\section{Teknik özellikler}

Ziller, çap, ağırlık, profil (kavis), göbek ve doğuşkanlarının farklılıklarına göre sınıflandirılmaktadır.

\section{1. Çap}

1.5 inç’ten $(3.8 \mathrm{~cm}) 24$ inç’e $(60.9 \mathrm{~cm})$ kadar farklı çapta ziller dökülmektedir. Zil büyüdükçe daha çok havayı hareket ettirmekte bu da daha fazla ses miktarına sebep olmaktadır. Çap genişledikçe büyük oranda metali birleştirmek daha çok güç ister. Bu yüzden büyük ziller küçük zillere oranla daha yavaş cevap verirler ve titreşimleri daha uzun sürer. Yine bu nedenle geniş zillerde tiz frekanslar daha düşüktür. Duyum açısından frekansları en temiz yansıtanlar orta büyüklükte olanlardır. Çapı dar zillerde tiz frekanslar belirgindir ve yayılım kisa olmaktadır ${ }^{11}$.

\subsection{A ğırlık}

50 gr ile $10 \mathrm{~kg}$ arasında farklı ağırlıklarda ziller üretilmektedir ${ }^{12}$. Zilin kalınlığı sesin miktarını ve karakterini etkiler. Ağır olanlarda tıpkı geniş ziller gibi ses miktarı daha çok, yayılım daha uzun ama cevap alınması daha yavaştır. Frekans aralığı daha dar ve tizler daha azdır. İnce zillerin bükülgenliği fazla olacağından kırılmaları daha çabuk olur. İnce zillerde yüksek frekanslar çabuk salınır ve sönerler. Orta ağırlıktaki zillerde yüksek frekanslar daha kalıcıdır. Zillerde göbekten kenarlara doğru kalınlık değişimi düz ve kademeli olarak iki şekilde olur. Kenarları ince olanlar daha çabuk cevaba ve sesin daha az yayılmasına sebep olurlar. Kalınlıktaki düzlük daha homojen bir sese yol açar (Pinsterboer, 1992: 71).

\subsection{Profil}

Tüm ziller temelde yassı diskler halindedirler. Zilin profili yani kavisi sahip olduğu tonu ve doğuşkanlarını etkilemektedir. Zil daha bombeli üretildiğinde metalin içindeki gerilme artmakta dolayısıyla doğuşkanlar azalmakta, ses kurulaşmaktadır. Kavisi daha düz olanlarda baskın ses azalır, doğuşkanlar çoğalır ve daha çabuk cevap verirler (Keskin, 2016). 


\subsection{Göbek}

Göbekler dar ve geniş olmak üzere ikiye ayrılır. Biçim olarak geniş, düz, dar ve yüksek olanlar görülür. Göbeğin varlığı zildeki sesin karakterinde değişiklikler yaratır. Geniş göbek, zilde cevap almayı kolaylaştırır. Dar göbekler sesin doğuşkanlarını azaltır. Göbeksiz zillerde ses kontrolü daha rahat sağlanır ${ }^{13}$.

\subsection{Doğuşkanlar}

Zil üzerindeki vuruşlar pek çok frekans üretir, bir notaya akortlu değillerdir. Böylelikle doğuşkan dizileri, periyodik titreşimlere, çapa, ağırlığa, göbeğe ve kavise bağlıdır. İyi kalitedeki bir zilin sesi geniş tonal ölçekteki frekansları içerir. Doğuşkanların sınırlı sayıda olması zil sesini sı̆̆ ve tek boyutlu yapar. Baskın ve kuvvetli olan ses irite edici olur ve çoğu zaman eserin tonuna göre detone kalmasına neden olur. Yüksek frekanslar vuruştan hemen sonra sönerler. Düşük frekanslar ise sesin uzamasıyla devam ederler. Esas baskın örgü bu iki ucun arasındadır. Ayrıca gövdeden, kenarlardan ve göbekten çıkan ses çok farklıdır. Bunlar birbirlerini etkileyerek başka doğuşkanlar da yaratırlar (Pinksterboer, 1992: 74).

\section{Zil çeşitleri}

Zaman içerisinde ve ihtiyaca göre ziller, çap, ağırlık, profil ve doğuşkanlarına göre kullanım alanlarına bağlı olarak çeşitli özelliklerde üretilmişlerdir. Davul setlerinde, senfonik orkestralarda, bandolarda ve efekt amaçlı kullanılmak üzere sınıflandırılabilirler.

Davul setlerinde kullanılanlar, Ride, Crash, Hihat, China, Splash (Carles vd, 1988: 70) $)^{14}$ gibi zillerdir. Eskiden takip zili adı verilen Ride ziller, 18-24 inç ${ }^{15}$ arasında farklı çaplara sahip, yüksek frekansların öne çıkmadığı, bununla birlikte geniş doğuşkanları olan, diğer çeşitlere göre daha kavisli, sürekli art arda vuruşlara uygun özelliklere sahiptir. Crash ziller, 14-20 inç arasında çaplara sahip, yüksek frekansların önde olduğu, kısa ve keskin seslerin elde edilmesinde kullanılırlar. China ziller, 16-21 inç arasında üretilmekte, crash zillere benzemekle beraber kenarları ters yönde düzleştirilmiş zillerdir. Kenarlarındaki düzlük, kısa ve keskin ses elde edilmesine neden olmaktadır. Kirli ve pürüzlü tınıya sahiptirler. Splash ziller, 8-14 inç arasında üretilen tiz ve dar frekanslara sahip küçük zillerdir. Hihat zilleri, 12-15 inç arası farklı çaplara sahip, düzeneğe yerleştirilip birbirlerine çarptırılarak veya üzerine vurularak çalınan zillerdir. Doğuşkanları az, yayılımları kısıtlıdır.

Senfonik orkestralar, bandolar ve özel amaçlar için kullanılan ziller ise Gonglar, Düz plakalar, elde tutularak çalınan çift zillerdir ${ }^{16}$. Ayrıca genellikle Doğu müziklerinde çalınan, tarihsel geçmişi en eskilerden olan küçük, parmak zilleri de üretilmektedir. Gonglar, 12-40 inç arası, oldukça ağır, pes frekansları fazla, yayılımları geniş, belli bir düzeneğe asılarak çalınan zillerdir. Çoğunlukla senfonik orkestralarda, zaman zaman spiritüel çalışmalarda ve rock müziğinde çalınmaktadır. Düz plakalar, tek tona sahip, göbeksiz, çapları dar, tekli veya set halinde çalınan disklerdir. Çift ziller, göbeklerinin ortasına takılan tutma aparatlarıyla elde, birbirlerine çarptırılmak suretiyle çalınırlar. 14-20 inç arası farklı çaplara sahiptirler. Doğuşkanları zengindir. Senfoni orkestraları ve bandolarda kullanılırlar. Parmak ziller ise küçük çaplı, tiz frekanslı, her iki elin iki parmağına takılarak birbirlerine çarptırılmak suretiyle çalınırlar. 


\section{Sonuç}

Araştırmada, tarihin en eski çalgılarından biri olan zillerin gelişmesinde rol oynayan Zildjian ailesi, zil yapımına katkıları, bu bağlamda Türkiye'de zil üretimi bütünsel bir çerçevede ortaya konmaya çalışılmıştır.

Zil yapımında dönüm noktası 17. yüzyılda gerçekleşmiştir. 1623 yılı İstanbul'da Kerope Zildjian'ın müstakil olarak zil yapımına başladığı tarihtir. Zildjian'lara kadar zilin kalitesi ve tınısında belli bir seviyeden bahsetmek mümkün değildir. Elle yapım zil üretimi zahmetli bir işlemdir. İşlemin her safhasında insana özgü değişkenlikler sonucu her zil birbirinden farklı olmakta bu da değerini arttırmaktadır. Aile mensupları bu zanaatte yıllar içinde giderek ustalaşmış dünya çapında ünlenmişlerdir. Babadan oğula geçen gelenekte, anne tarafından Zildjian olan Mikhail Zilçan, ailenin ABD’ne taşınmasından sonra İstanbul'da kalmış kendi üretimini sürdürmüştür. Kimi deklarasyon ve yazışmalar göstermektedir ki iki taraf arasında belli bir uyuşmazlık vardır. ABD’ndekiler Mikhail Zilçan'ın ürettiği zilleri beğenmemektedirler ve kendi soyadlarının damga olarak kullanılmamasını istemektedirler. Bu doğrultuda 1950 yılında tüm isim haklarını satın alırlar. Her ne kadar Zildjian'lar Mikhail Zilçan'a pek değer vermemelerine rağmen, 1923 ’ten 1977 yılına kadar atölyesinde yetiştirdiği çıraklar bu zanaatte gelişmiş ve ilerlemişlerdir. 1980'li yıllardan bu yana kendi atölyelerinde ürettikleriyle zil dünyasında önemli köşe taşlarını oluşturmaktadırlar. "Türk zilleri” mefhumu zil tarihinde itibar kaynağıdır. \%100 el yapımı üretim yapan firmaların çoğu İstanbul'dadır ve Mikhail Zilçan'ın atölyesinden yetişen ustaların yanında yetişen ustalara aittir. Böylelikle gerek Zildjian'lar gerek Mikhail Zilçan’ın kültürel mirasçıları, efsaneye uygun kalitede zil üretimini halen devam ettirmektedirler. Alaşımın sır olduğu zamanlar geride kalmakla beraber hala her üreticinin kendi tınısından bahsetmek mümkündür. Günümüzde ziller, doğuşkanlarına, fonksiyonlarına, estetik şekillerine göre çok çeşitlilik göstermektedir. Antik zamanlardan günümüze zil yapımındaki gelişmede "Türk zilleri”, hem tarihsel hem çağdaş dönemde önemli olmuş ve bu önemi sürdürmeyi başarmıştır.

\section{Notlar}

1. İdiofon: Zil, kastanyet, çan gibi sesleri kendinde olan çalgılar. Vurma, koparma, üfleme, titretme benzeri hareketlerle çalınırlar.

2. Membranofon: Derilerin gerilerek bir kasnağa monte edilmesiyle oluşan çalgılar. Vurarak çalınırlar.

3. Mehmet Tamdeğer, Habertürk kanalında yayınlanan “Emeğin Öyküsü-Zil Yapımı” adlı programda bu bilgileri paylaşmıştır.

4. Zildjian ailesini gösteren şema üç farklı kaynaktan kronolojik sıra göz edilerek oluşturulmuştur. Özellikle I. Kerope'den sonraki üç nesle ilişkin bilgilerde eksiklikler mevcuttur. Bir kısmının doğum ve ölüm bilgileri yoktur. Ancak 19. yüzyıldan sonra bilgiler kesinlik kazanmaktadır.

5. 1680'de Strungk'ın “Ester”, 1779'da Gluck'un “İphigenie en Tauride” (Beck, 1995: 169), 1794'te Haydn'ın "Askeri Senfonisi”, Mozart'ın "Saraydan Kız Kaçırma” operası gibi eserler örnek verilebilir.

6. Sabian firmasının kuruluşuyla ilgili bilgiler kendi web siteleri üzerinden sağlanmıştır.

7. Haluk Özözlü, 10 Mayıs 1992 yılında Show Dergisi için yaptığı röportajda Agop ve Mehmet ustalardan bu bilgileri aktarmıştır. 
8. "İstanbul" firmasının dağılmasıyla ortaya çıkan yeni firmalara ilişkin bilgiler ilgili firmaların internet siteleri üzerinden sağlanmıştır. "Turkish" ve "Bosphorus" firmalarının sahipleri Agop Tomurcuk ve Mehmet Tamdeğer'in yanında yetişen birinci kuşak ustalardır. Günümüzde başka firmalar da kurulmuştur fakat onların sahipleri sonraki kuşak ustalardandır. Dolayısıyla Zildjian ve ilk kuşak ustalarla ilgili birebir bağlantı onlarda bulunmamaktadır. Bu bakımdan konuya dahil edilmemişlerdir.

9. Mikhail Zilçan'ın atölyesinde çalışmaya başlayan çıraklar Agop, Mehmet, Artin, Garbis, Oksant, Avram gibi aynı aileden veya Ermeni cemaatinden 9-10 yaşlarında çocuklardır. Mehmet Tamdeğer belirttiğine göre aralarındaki tek Türk’tür. Agop, Mehmet ve Artin ustalar bu isimler içinde zil yapımını uzun süre sürdüren isimler olmuşlardır (Bir Dünya İnsan-Zilci, 2017, Onat, 1997: 13).

10. Mehmet Tamdeğer, zil yapım aşamalarını tvnet.'de yayınlanan “Bir Dünya İnsan-Zilci” belgeselinde ayrıntılarıyla ifade etmektedir.

11. Zillerin çaplarıyla ilgili bilgiler kaynakçada adı geçen üretici firmaların web sayfalarındaki bilgilerin karşılaştırmalı derlenmesiyle elde edilmiştir.

12. Rusya'da üretime başlayan sonradan çeşitli Avrupa ülkelerinde faaliyet gösteren Paiste firmasının web sitesinde zillerin teknik bilgileri verilmektedir.

13. Sabian firmasının kendi web sayfasında zillerle ilgili teknik bilgiler paylaşılmıştır.

14. Zil çeşitlerini belirleyen isimlerde Türkçe terminoloji gelişmemiştir dolayısıyla gerek müzisyenler gerek firmapazar ilişkilerinde İngilizce terminoloji kullanıldığından metin içinde aynı şekilde yer almıştır. Adı geçen zil çeşitleri III. Avedis'in üretimleriyle ortaya çıkmıştır.

15. Ölçüler konusunda Türkiye'de metrik sistem uygulanmasına rağmen yerli firmaların da yurt dışına ithalat yapmaları sonucu "inç"i birim olarak kullanmalarından kaynaklı yerleşik söylem esas alınmıştır.

16. Zildjian firmasının web sayfasında zil tasniflerine ilişkin geniş bilgiler yer almaktadır.

\section{Kaynaklar}

Adıgüzel, H. (2019). Bir tasarımın izinde: Yeni bulgular ışığında Raimondo D’Aranco'nun ilk İstanbul projesi dersaadet ziraat ve sergi-i umumisi. Metujfa, S. (36:1), ss. 157-182.

Aksoy, B. (1994). Avrupalı gezginlerin gözüyle Osmanlılarda musıki. İstanbul: Pan.

Beck, John H. (1995). Encyclopedia of percussion. New York-Londra: Garland.

Blades, J. (1984). Percussion instruments and their history. Connecticut: The Bold Strummer.

Carles, P., Clergeat, A. ve Comolli, JL. (1988). Dictionnaire du jazz. Paris: Robert Laffont.

Cohan, J. (1999). Zildjian; a history of the legend cymbal makers. Wisconsin: Hal \& Leonard.

Kennedy, M. (1996). The concise Oxford dictionary of music. Oxford- New York: Oxford University.

Mimaroğlu, İ. (1987). Müzik tarihi. İstanbul: Varlık.

Onat, A. (1997). Onların zilinin tınısı başka. Cumhuriyet Gazetesi. 20 Nisan, S. 578

Özdemir, N. (1997). Anadolu halk kültüründe resim, heykel ve müziğin yeri, önemi. Ankara: Nurol.

Paczynski, G. (1997). Une histoire de la batterie de jazz. Paris: Outre Mesure.

Pinksterboer, H. (1992). The cymbal book. Wisconsin: Hal \& Leonard.

Redmond, L. (1997). When the drummers were women, a spiritual history of rhtythm. New York: Three Rivers.

Sachs, C. (1940). The history of musical instruments. New York: W.W. Norton \&Company.

Sözer, V. (1986). Müzik ve müzisyenler ansiklopedisi. İstanbul: Remzi.

Tanrıkorur, C. (2003). Osmanlı dönemi Türk mûsikîsi. İstanbul: Dergâh.

Tuğlacı, P. (1986). Mehterhane'den bando'ya. İstanbul: Cem.

Tunçer, B. (2005). Eskiçă̆ Kilikia çalgıları. İstanbul: Pan. 


\section{Elektronik kaynaklar}

Bir dünya insan-Zilci. (2017).

Erişim adresi: https://www.youtube.com/watch?v=qfVpZFpzwS4 (Erişim: 21 Ağustos 2019).

Keskin, H. Emeğin öyküsü-Zil yapımı. (2016). Erişim adresi: https://www.youtube.com/ watch? $=0$ Tu0ph1T5ac (Erişim: 20 Ağustos 2019).

Özözlü, H. Zil dünyası. Erişim adresi: http://www.sihirlitur.com/belgesel/zil_dunyasi/index.html (Erişim: 20 Ağustos 2019).

Bosphorus. Erişim adresi: http://bosphoruscymbals.com/company/about-us/ (Erişim: 10 Aralık 2019)

İstanbul Agop. Erişim adresi: https://istanbulcymbals.com/about-history.html (Erişim: 10 Aralık 2019)

İstanbul Mehmet. Erişim adresi: https://www.istanbulmehmet.com/\#section-work (Erişim:10 Aralık 2019)

Paiste. Erişim adresi: http://www.cymbal.wiki/wiki/Paiste_Weight_Table (Erişim: 5 Ağustos 2019).

Sabian. Erişim adresi: https://sabian.com/en/pages/anatomy-of-a-cymbal (Erişim: 18 Ağustos 2019).

Turkish. Erişim adresi: http://turkishcymbals.com/ (Erişim: 10 Aralık 2019)

Zildjian. Erişim adresi: https://zildjian.com (Erişim: 10 Ağustos 2019). 